\title{
Expression and cellular localization of insulin-like growth factor-II protein and mRNA in Sparus aurata during development
}

\author{
G Radaelli, M Patruno, L Maccatrozzo and B Funkenstein ${ }^{1}$ \\ Department of Experimental Veterinary Sciences, Faculty of Veterinary Medicine, University of Padua, Italy \\ ${ }^{1}$ Israel Oceanographic and Limnological Research, National Institute of Oceanography, Haifa, Israel \\ (Requests for offprints should be addressed to G Radaelli, University of Padua, Faculty of Veterinary Medicine, Department of Experimental Veterinary \\ Sciences, Agripolis, 35020 Legnaro (PD), Italy; Email: giuseppe.radaelli@unipd.it)
}

\begin{abstract}
The spatial localization of IGF-II protein and mRNA was investigated during larval and postlarval developmental stages of the gilthead sea bream (Sparus aurata) by immunohistochemistry and in situ hybridization, using specific antisera and riboprobes. Steady-state levels of IGF-II mRNA in larvae were determined by Northern blot analysis and were found to be increased. Immunoreactivity towards IGF-II was found in larval skin, muscle, gills, gut, olfactory epithelium and kidney. After metamorphosis, the strongest immunoreactivity was found in red skeletal muscle. Positive reaction with IGF-II antibodies was also found in the olfactory epithelium and in the epithelia of pharynx, oesophagus, stomach and kidney. In
\end{abstract}

the adult, the most intense signal was observed in the red and pink musculature and in heart musculature. Immunostaining was also found in saccus vasculosus, thymus, spleen and ovary. IGF-II mRNA was detected by in situ hybridization in the brain, olfactory epithelium, eye, pharynx, skeletal musculature and liver. The spatial distribution of IGF-II shown in this study is consistent with previous findings on the cellular localization of IGF type 1 receptor in the sea bream and supports a role for IGF-II during development and growth of sea bream. Furthermore, these results suggest that IGF-II acts in an autocrine/paracrine manner.

Journal of Endocrinology (2003) 178, 285-299

\section{Introduction}

Insulin-like growth factors (IGFs) are evolutionarily ancient polypeptides, widely distributed throughout vertebrates, ubiquitously expressed and with potent metabolic and mitogenic action, that affect cell development and growth. In addition to endocrine effects exerted by circulating IGFs, these growth factors may act in a paracrine/autocrine fashion, stimulating cell proliferation in a variety of tissues (Jones \& Clemmons 1995). Several studies have indicated that in fish, as in mammals, the IGF system consists of two ligands (IGF-I and IGF-II), several binding proteins, and high-affinity transmembrane receptors that belong to the insulin/IGF receptor family (reviewed in Peter \& Marchant 1995, Reinecke \& Collet 1998, Moriyama et al. 2000). Mature IGFs-I and -II consist of B, C, A and D domains and their structure is similar to that of proinsulin, which consists of $\mathrm{B}, \mathrm{C}$ and $\mathrm{A}$ domains (Humbel 1990). The biological effects of IGFs are mediated mainly through binding to the IGF type 1 receptor (IGF-IR), which is localized on the cell membrane. In biological fluids, IGFs are normally bound to IGF binding proteins (IGFBPs) (Jones \& Clemmons 1995, Kelley et al. 2002).
IGF-II is a 67-amino acid single-chain polypeptide that shows structural sequence similarity to both IGF-I and insulin. In mammals, production of IGF-II has been demonstrated mainly in liver (Jones \& Clemmons 1995), although experimental data demonstrated expression of IGF-II in other tissues also (Reinecke \& Collet 1998). Several lines of evidence support the hypothesis that IGF-II has an important role during mammalian fetal development (Han et al. 1988, Daughaday \& Rotwein 1989, DeChiara et al. 1990, Singh et al. 1991). However, the concentration of IGF-II in adult human serum, brain and gonads remains increased, suggesting an important role during adult life also (Gluckman \& Ambler 1993).

Contrasting with mammals, many fish species continue to grow throughout adult life and attain a large size as a result of extensive postlarval muscle hyperplasia (Rowlerson \& Veggetti 2001). Hence, teleosts can serve as an important model for analysis of the roles of IGF in growth.

The cDNA sequences encoding IGF-II have been characterized in numerous fish species: rainbow trout (Oncorhynchus mykiss) (Shamblott \& Chen 1992), gilthead sea bream (S. aurata) (Duguay et al. 1996), barramundi (Lates calcarifer) (Collet et al. 1997), tilapia (Oreochromis 
mossambicus) (Chen et al. 1997), Coho salmon (Oncorhynchus kisutch) (Palamarchuk et al. 1997), Japanese pufferfish (Fugu rubripes) (Clark 1998), zebrafish (Brachydanio rerio) (Maures et al. 2002), daddy sculpin (Cottius scorpius) (Loffing-Cueni et al. 1999), carp (Cyprinus carpio) (Tse et al. 2002), turbot (Psetta maxima) (Duval et al. 2002) and rabbitfish (Siganus guttatus) (Ayson et al. 2002). Although the main source of IGF-II in fish, as in mammlas, is liver (Palamarchuk et al. 1999), IGF-II gene expression has been demonstrated in a variety of extrahepatic tissues of fish (Shamblott \& Chen 1992, Duguay et al. 1996, Collet et al. 1997, Loffing-Cueni et al. 1999, Schmid et al. 1999, Degger et al. 2001, Tse et al. 2002).

Relatively very little is known of the roles of IGF-II in fish, as it has not been purified from native sources and that obtained by recombinant technology has been only partially characterized (Gentil et al. 1996, Chen et al. 1997, 2000, Degger et al. 2001, Duval et al. 2002). Gentil et al. (1996) produced recombinant rainbow trout IGF-II for the development of an RIA, in order to measure IGF-II concentrations in fish serum. Subsequently, Chen et al. (1997, 2000) demonstrated that recombinant tilapia IGF-II stimulated DNA synthesis in tilapia ovarian cells in vitro and significantly increased body weight and body length when injected into juvenile tilapia. Recombinant barramundi IGF-II stimulated protein synthesis in L6 rat myoblasts (Degger et al. 2001) and recombinant turbot IGF-II inhibited release of growth hormone from turbot pituitary cells in culture (Duval et al. 2002). Likewise, information on the ontogeny and expression of IGF-II is relatively scarce in fish and limited to only a few species. Thus transcripts for IGF-II were detected in unfertilized eggs, embryos and larvae of sea bream (Duguay et al. 1996, Perrot et al. 1999), rabbitfish (Ayson et al. 2002), embryos of rainbow trout (Greene \& Chen 1997, 1999) and carp eggs and larvae (Tse et al. 2002). In contrast to mammals, in fish the IGF-II gene is expressed at a high level from the early stages of embryonic development until the adult stage, indicating a physiological importance of IGF-II 'under water'. Nevertheless, the precise cellular localization of IGF-II peptide at these early developmental stages or in adult fish is not known.

The aim of this study was to characterize the cellular localization of IGF-II peptide and mRNA in the gilthead sea bream ( $S$. aurata), using homologous antibodies and riboprobes. This marine fish is of high importance for the aquaculture industry because of its high commercial value.

\section{Materials and methods}

\section{Chemicals}

Oligonucleotides were prepared by Universal DNA Inc. (Tigard, OR, USA) and Sigma. Restriction and modifying enzymes were purchased from New England Biolabs (Beverly, MA, USA) and Promega. Recombinant human
IGF-II was purchased from R\&D systems (Minneapolis, MN, USA).

\section{Fish samples and tissue processing}

Larvae and fry of sea bream were obtained from fish hatcheries at Pellestrina (VE, Italy) and from the National Center of Mariculture (Eilat, Israel) and killed by an overdose of MS222 (Sandoz, Milan, Italy) anaesthesia. Animals and tissues used for both immunohistochemistry and in situ hybridization were fixed in 4\% paraformaldehyde prepared in PBS $(0.1 \mathrm{M}, \mathrm{pH} 7.4)$ at $4{ }^{\circ} \mathrm{C}$ overnight. Small fish (hatching to juveniles) were fixed in toto and longitudinal (both frontal and sagittal) and transversal sections were cut. Organ and tissue samples were dissected out from large adult fish (mature males and females during the spawning season) and processed separately. Samples for RNA extraction were frozen immediately on dry ice and kept at $-70{ }^{\circ} \mathrm{C}$ until required for RNA extraction.

\section{Immunohistochemistry}

Fixation and embedding Larvae $(3,5,10,15,18,22$, 29 and 36 days) and fry (77, 95 and 110 days), fixed as mentioned above, were washed in PBS, dehydrated through a graded series of ethanol and embedded in paraffin. Dewaxed sections were cut serially at a thickness of $4 \mu \mathrm{m}$ using a microtome.

Antisera Polyclonal antibodies were raised in mice against a synthetic peptide spanning amino acids 28-42 in the mature sequence (between the $\mathrm{B}$ and $\mathrm{C}$ domain) (Eurogentec, Brussels, Belgium), which includes a region that discriminates between IGFs-I and -II (Duguay et al. 1996). The antibodies were used at a dilution of 1:500.

Immunohistochemical procedure The immunohistochemical reactions were performed using the Envision method (goat anti-mouse immunoglobulins conjugated to peroxidase-labelled complex; Dako, commercial kit, ready for use). Before the primary antibody was applied, endogenous peroxidase activity was blocked by incubating the sections in $3 \% \mathrm{H}_{2} \mathrm{O}_{2}$ in PBS and non-specific binding sites were blocked by incubation in 1:5 non-immune serum from the animal species producing the secondary antibody. The primary antisera were applied overnight at $4{ }^{\circ} \mathrm{C}$ in a humid chamber. After rinsing in PBS buffer, the sections were incubated for $30 \mathrm{~min}$ at room temperature in Envision system. After washes in PBS, the immunoreactive sites were visualized using a freshly prepared solution of $10 \mathrm{mg}$ of 3,3'-diaminobenzidine tetrahydrochloride (Sigma) in $15 \mathrm{ml} 0 \cdot 5 \mathrm{M}$ Tris buffer at $\mathrm{pH} 7 \cdot 6$, containing $1 \cdot 5 \mathrm{ml} 0 \cdot 03 \% \mathrm{H}_{2} \mathrm{O}_{2}$. In order to ascertain structural details, sections were counterstained with Mayer's haematoxylin, dehydrated and mounted in Eukitt, and examined under an Olympus BX50 photomicroscope. 
Controls The specificity of the immunostaining was verified: (1) by incubating sections with PBS instead of the specific primary antisera; (2) by incubating sections with preimmune sera instead of primary antisera; (3) by incubating sections with PBS instead of secondary antibodies; (4) by absorption of the antisera with excess of synthetic peptide $(3 \mu \mathrm{g} / \mu \mathrm{l})$ before incubation with sections. The results of these controls were negative (i.e. staining was abolished).

\section{Molecular cloning}

A $210 \mathrm{bp}$ fragment of sea bream IGF-II cDNA coding for the mature IGF-II protein was cloned in PGEM-Teasy (Promega) for generating riboprobe and in pET11a (Novagen, Madison, WI, USA) for expressing sea bream IGF-II in bacteria (B Funkenstein, G Radaelli, M Patruno \& L Maccatrozzo, unpublished observations). A second plasmid containing a 466 bp of sea bream IGF-II cDNA was cloned in pCRII-TOPO (Invitrogen). This cDNA fragment hybridized specifically with sea bream IGF-II cDNA (Perrot et al. 1999).

\section{Synthesis of $R N A$ probe}

Linearized sea bream IGF-II cDNAs were used as template to generate sense and antisense RNA probes by using bacteriophage SP6 or T7 RNA polymerases according to a procedure modified from Nieto et al. (1996). The reagents were added at room temperature in the following order: $10 \mu \mathrm{l}$ sterile distilled water, $4 \mu \mathrm{l} 5 \times$ transcription buffer (Promega), $2 \mu \mathrm{l}$ 0.1 M dithiothreitol (Promega), $2 \mu \mathrm{l}$ digoxigenin (DIG) nucleotide mix $\mathrm{pH} 8 \cdot 0$ (Roche), $1 \mu \mathrm{l}$ linearized IGF-II plasmid $(1 \mu \mathrm{g} / \mu \mathrm{l}), 0 \cdot 5 \mu \mathrm{l}$ ribonuclease inhibitor $(100 \mathrm{U} / \mu \mathrm{l})$ (Roche), $1 \mu \mathrm{l}$ T7 or SP6 RNA polymerase $(10 \mathrm{U} / \mu \mathrm{l}$, Promega). After incubation at $37^{\circ} \mathrm{C}$ for $2 \mathrm{~h}, 2 \mu \mathrm{l}$ ribonuclease-free DNase I (Roche) were added and incubation was continued for an additional $15 \mathrm{~min}$. Precipitation of the synthesized RNA was achieved by adding $100 \mu \mathrm{l}$ Tris-EDTA buffer (TE), $10 \mu \mathrm{l}$ $4 \mathrm{M}$ lithium chloride and $300 \mu \mathrm{l}$ ethanol and storing the tube at $-20{ }^{\circ} \mathrm{C}$ for $30 \mathrm{~min}$. The RNA was then centrifuged at 13000 r.p.m. for $10 \mathrm{~min}$ and the pellet washed with $70 \%$ ethanol and air-dried. The RNA was reconstituted in $50 \mu \mathrm{T} \mathrm{TE}$ and $5 \mu \mathrm{l}$ were run on a $1 \%$ agarose/Tris-borate-EDTA gel to assess its quality and concentration. The RNA probe was diluted to $0 \cdot 1 \mu \mathrm{g} / \mu \mathrm{l}$ and stored at $-80{ }^{\circ} \mathrm{C}$.

\section{In situ hybridization procedures}

Whole mounts of larvae of 3, 5, 10, 15, 22, 29 and 36 days, fixed as mentioned above, were washed in PBS twice, dehydrated and stored in methanol at $-20{ }^{\circ} \mathrm{C}$. After hydration in graded methanol, larvae were processed as described earlier (Joly et al. 1993), with slight modifi- cations as follows. After incubation in $6 \% \mathrm{H}_{2} \mathrm{O}_{2}$ for $30 \mathrm{~min}$, larvae were permeabilized by treatment with $10 \mu \mathrm{g} / \mathrm{ml}$ proteinase $\mathrm{K}$ (Roche) in PBS containing $0 \cdot 1 \%$ Tween 20 (PBT) for $20 \mathrm{~min}$ (duration of treatment depended on the size of the sample), washed in PBT and fixed again in $4 \%$ paraformaldehyde plus $0 \cdot 2 \%$ glutaraldehyde for $20 \mathrm{~min}$ before the hybridization step. After washing in PBT, larvae were rinsed with 1:1 PBT/ hybridization solution and then incubated with hybridization solution, prewarmed to $60{ }^{\circ} \mathrm{C}$, for $30 \mathrm{~min}$. This was replaced with a fresh hybridization solution containing $0 \cdot 1 \mu \mathrm{g} / \mu \mathrm{l}$ RNA probe and incubation continued overnight at $55-60{ }^{\circ} \mathrm{C}$. Transcripts were identified by using the DIG nucleic acid detection kit (Roche). The hybridized larvae were viewed using a stereomicroscope connected to a digital camera (Olympus). After in situ hybridization, larvae were kept in PBT containing $100 \mathrm{mM}$ EDTA at $4{ }^{\circ} \mathrm{C}$. For histological examination, hybridized larvae were dehydrated and embedded in paraffin. Serial sections $10 \mu \mathrm{m}$ thick were occasionally counterstained with haematoxylin, dehydrated, mounted in Eukitt and examined under an Olympus BX50 photomicroscope.

Paraffin sections of larvae were processed for in situ hybridization experiments as described earlier (Del Giacco et al. 2000), except for the revelation step, in which antidigoxigenin conjugated with fluorescein had been used at dilutions recommended by the manufacturer (Roche). Images were obtained with a Leica TCS-SP2 confocal laser scanning microscope.

\section{Gel electrophoresis and western blot}

Total cellular proteins from Escherichia coli BL21(DES) cells expressing sea bream IGF-II were analysed by TricineSDS-polyacrylamide (16\%) gel electrophoresis (Schagger \& Von Jagow 1987). Gels were stained with Coomassie Brilliant Blue R-250. For western blot, proteins were electrotransferred to nitrocellulose membranes and reacted with a 1:1500 dilution of specific polyclonal antibodies raised in mice against a synthetic peptide of sea bream IGF-II (see above). Membranes were then incubated with biotinylated goat anti-mouse $\operatorname{IgG}(\mathrm{H}+\mathrm{L})$, affinity purified (Vector Labs, Burlingame, CA, USA; diluted to a final concentration of $0.75 \mu \mathrm{g} / \mathrm{ml}$ ). Detection was accomplished by the avidin-biotin reagent (Vectastain, $\mathrm{ABC}$ kit, Vector Labs) and 3,3'-diaminobenzidine in $\mathrm{H}_{2} \mathrm{O}_{2}$.

\section{$R N A$ preparation and northern blots}

Total RNA was extracted from pools of whole bodies of larvae by the guanidinium-rapid method (Chomczynski \& Sacchi 1987). Poly $\left(\mathrm{A}^{+}\right)$RNA was isolated by chromatography on oligo(dT) cellulose (Aviv \& Leder 1972). RNA was electrophoresed in a $1 \%$ agarose gel containing $0.66 \mathrm{M}$ formaldehyde and transferred to a nylon membrane. 


\section{Days post-hatching}

$\begin{array}{llllll}1 & 6 & 10 & 15 & 21 & 22\end{array}$

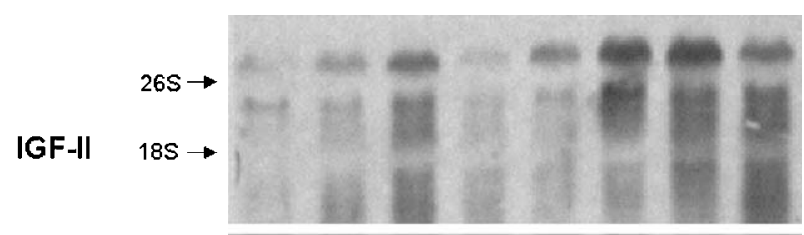

\section{B-ACTIN}

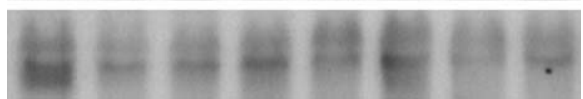

Figure 1 IGF-ll gene expression in $S$. aurata larvae. Poly $\left(\mathrm{A}^{+}\right) \mathrm{RNA}$ $(12 \mu \mathrm{g})$ prepared from a pool of larvae collected 1, 6, 10, 15, 21, 22, 25 and 27 days after hatching was fractionated on 1\% agarose gels and transferred to nylon membranes. The RNA was hybridized with IGF-II cDNA and re-hybridized with sparus $\beta$-actin cDNA shown below. The IGF-II blot was exposed for 1 day with an intensifying screen and the $\beta$-actin blot for 1 day without an intensifying screen.

Hybridization was performed at $42{ }^{\circ} \mathrm{C}$ in a solution containing $50 \%$ formamide. Filters were hybridized first to phosphorus-32-labelled S. aurata IGF-II cDNA (Duguay et al. 1996), labelled by random priming method, and then to $S$. aurata $\beta$-actin partial cDNA (kindly provided by Dr M Tom, IOLR, Haifa, Israel). Northern blots were exposed to Kodak XAR-5 film (Eastman Kodak, Little Chalfont, UK) and intensifying screens at $-70{ }^{\circ} \mathrm{C}$ for various periods of time, depending on the signal obtained.

\section{Results}

\section{Developmental expression of IGF-II $m R N A$}

The ontogeny of IGF-II expression was determined in poly $\left(\mathrm{A}^{+}\right)$RNA samples extracted from pools of whole larvae collected on days 1, 6, 10, 15, 21, 22, 25 and 27 post-hatching [similar to those used for the determination of IGFBP-2 expression (Funkenstein et al. 2002)]. Blots were hybridized to labelled $S$. aurata IGF-II cDNA (Duguay et al. 1996). As shown in Fig. 1, a major transcript of about $4.8 \mathrm{~kb}$ was detected as early as on day 1 after hatching, although the concentrations were very low. The concentrations increased on day 6 and reached a peak on day 10 . Thereafter, they decreased, with a second increase observed on days 22 and 25 post-hatching. The size of the transcript and apparently high background were similar to those reported earlier for liver IGF-II mRNA of $S$. aurata (Duguay et al. 1996). The expression of $\beta$-actin gene in these pools of larvae is shown in the lower panel of Fig. 1.

Immunodetection of recombinant sparus IGF-II by anti-sparus IGF-II antibodies

Results obtained by expression of recombinant sparus IGF-II (saIGF-II) are shown in Fig. 2A. Induction of E. coli BL21(DE3) cells transformed with $\mathrm{pET} / \mathrm{saIGF}-$ II by isopropyl thiogalactoside for $3 \mathrm{~h}$ resulted in the appearance of a band with an approximate molecular mass

(A)

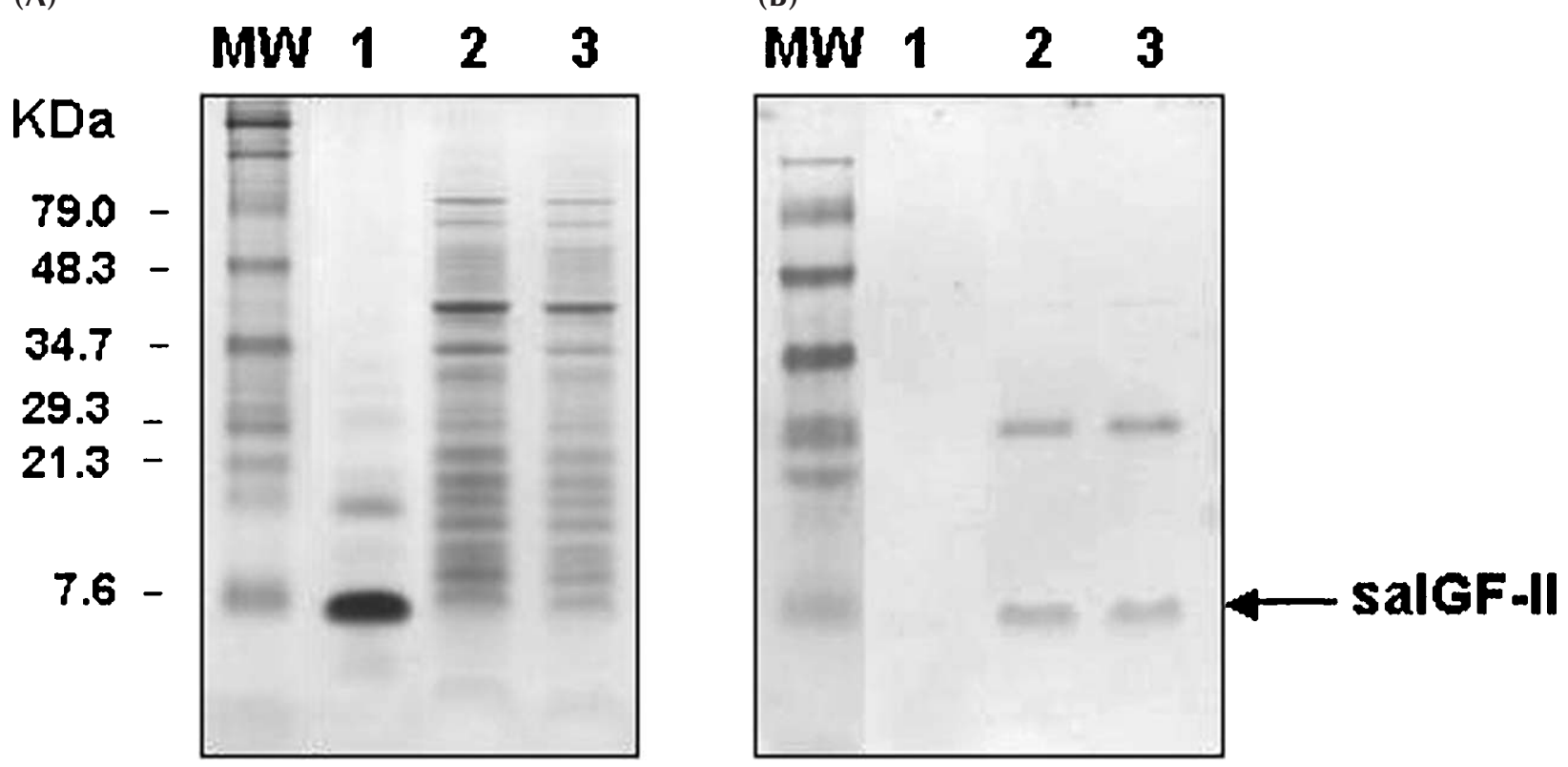

Figure 2 SDS-PAGE and western blot analyses of E. coli bacteria expressing recombinant S. aurata IGF-II. (A) Coomassie Blue staining; (B) immunoblot using anti-S. aurata IGF-II serum. Lane 1, recombinant human IGF-II; lanes 2 and 3, cell lysate from two different clones after induction with isopropyl thiogalactoside. MW, molecular mass standards. 
Table 1 Immunohistochemical localization of IGF-II in sea bream

\begin{tabular}{|c|c|c|c|}
\hline & $\begin{array}{l}\text { Larval } \\
\text { stage }\end{array}$ & $\begin{array}{l}\text { Postlarval } \\
\text { stage }\end{array}$ & Adult \\
\hline \multicolumn{4}{|l|}{ Tissue } \\
\hline Skeletal muscle & $\begin{array}{l}+++ \\
(\mathrm{W})\end{array}$ & $\begin{array}{l}+++ \\
(\mathrm{R})\end{array}$ & $\begin{array}{l}+++ \\
(R, P)\end{array}$ \\
\hline Gut epithelium & $+++/++$ & ++ & + \\
\hline Kidney epithelium & + & ++ & $\mathrm{n}$ \\
\hline Gill epithelium & ++ & ++ & $\mathrm{n}$ \\
\hline Skin & ++ & ++ & ++ \\
\hline Pancreas & - & - & - \\
\hline Liver & + & + & + \\
\hline Olfactory epithelium & ++ & ++ & * \\
\hline
\end{tabular}

Staining: - , not detectable; + , slight but above background levels; ++ , moderate; +++ , marked; $+++/++$, high in young larvae (3-10 days) and lower in later stages.

${ }^{*}$ Tissues not found on the sections examined at this stage; $\mathrm{n}$, not examined in this stage; R, P, W, red pink and white muscle fibres.

of $7 \mathrm{kDa}$ (lanes 2 and 3). A recombinant human IGF-II, which served as reference (lane 1) gave a band of a similar size. The putative bands of saIGF-II reacted positively when incubated with polyclonal antibodies raised against a synthetic peptide of saIGF-II (Fig. 2B), confirming the identity of the $7 \mathrm{kDa}$ bands as being saIGF-II. Furthermore, these results indicated that the antibodies prepared against a short synthetic peptide could potentially recognize tissue IGF-II and are suitable for immunohistochemical localization of IGF-II in S. aurata larvae and post-larvae. A band of $29 \mathrm{kDa}$ that also reacted with the antibody might be recombinant IGF-II that remained as oligomers.

\section{Immunohistochemical localization of IGF-II}

Analysis by northern blot (this study) or by RT-PCR (Perrot et al. 1999) and Ribonuclease Protection Assays (RPA) (Duguay et al. 1996) provided information on the expression of IGF-II in pools of $S$. aurata larvae or in tissues from adult fish. It did not provide any information regarding the cellular localization or whether the RNA is translated into a protein. To answer these questions, in situ hybridization and immunohistochemistry were performed using larval, postlarval and adult tissues.

General The results of IGF-II immunostaining in the different tissues are described in the text below and are shown in representative sections. The main observations are also summarized in Table 1.

\section{Larval stages}

During larval life, reactivity was found in skin, muscle, gills, gut, olfactory epithelium and kidney (Table 1, Fig. 3A-H). In the skin of 3-day larvae, an intense IGF-II immunoreactivity was detected in the epidermis (Fig. 3A). In skeletal muscle, IGF-II immunoreactivity was detected in the white fibres of 3 day-larvae (Fig. 3A), which remained high in 10-day larvae (Table 1). The high levels of IGF-II protein in muscle of young larvae were corroborated by high levels of IGF-II mRNA shown by in situ hybridization (see Fig. 6B, E). An intense IGF-II immunoreactivity was found in the olfactory epithelium (Fig. 3B) and in the epithelium of the developing gut in young larvae (Table 1). IGF-II immunoreactivity in the gut was less intense as gut development progressed. Thus a faint IGF-II immunoreactivity was found in the enterocytes of the proximal intestine (Fig. $3 \mathrm{C}$ ), whereas a more intense reaction was noted in the apical portion of the epithelium in the developing distal intestine (Fig. 3D). The liver parenchyma exhibited faint immunostaining (Fig. 3D), whereas the pancreas was negative (Table 1). In the gills, immunoreactivity appeared in scattered cells of the epithelium at the level of primary and secondary lamellae (Fig. 3E). Immunostaining was also detected in the epithelium of the branchial cavity (Fig. 3E,F). The epithelium of renal tubules in the anterior part of the kidney also displayed a positive reaction (Fig. $3 \mathrm{H}$ ).

Postlarval stages After metamorphosis, strong immunostaining was detected in the skeletal musculature, at the level of red fibres (Fig. 4A). A positive reaction was also detected in the olfactory epithelium (Fig. 4B) and in striated muscle fibres surrounding the eyes (data not shown). In the gut, strong IGF-II immunoreactivity occurred in the epithelium of the pharynx (Fig. 4C), with a lower intensity in the oesophagus and stomach epithelia (Fig. 4D and $\mathrm{E}$ respectively). In addition, a faint immunoreactivity was detected in the striated musculature of the oesophagus (Fig. 4D) and in gastric pits of the stomach (Fig. 4E). IGF-II immunoreactivity was not confined to enterocytes, but extended to the brush border also (data not shown). The reactivity in liver was weak and not evenly distributed (Fig. 4D), whereas pancreas showed a negative reaction (Fig. 4E). In gills, immunoreactivity appeared in scattered cells of the epithelium of both primary and secondary lamellae (Fig. 4F). An intense IGF-II immunostaining was found in the epithelium and brush border of renal tubules in the head kidney (Fig. 4G) and in the epithelium surrounding the thymus, in addition to some regions within the thymus (Fig. $4 \mathrm{H}$ ).

Adults In skeletal muscle, strong immunostaining was present in the red fibres and in the pink muscle layer (Fig. 5A). The white deep muscle fibres were negative, irrespective of diameter (Fig. 5A). In the heart, positive immunostaining was detected in the muscle fibres (Fig. 5B). IGF-II immunoreactivity was also found in the parenchyma of the spleen, in scattered cells (Fig. 5C). In the ovary, IGF-II immunoreactivity was detected in oocytes (perinucleolus stage) and in granulosa and theca 

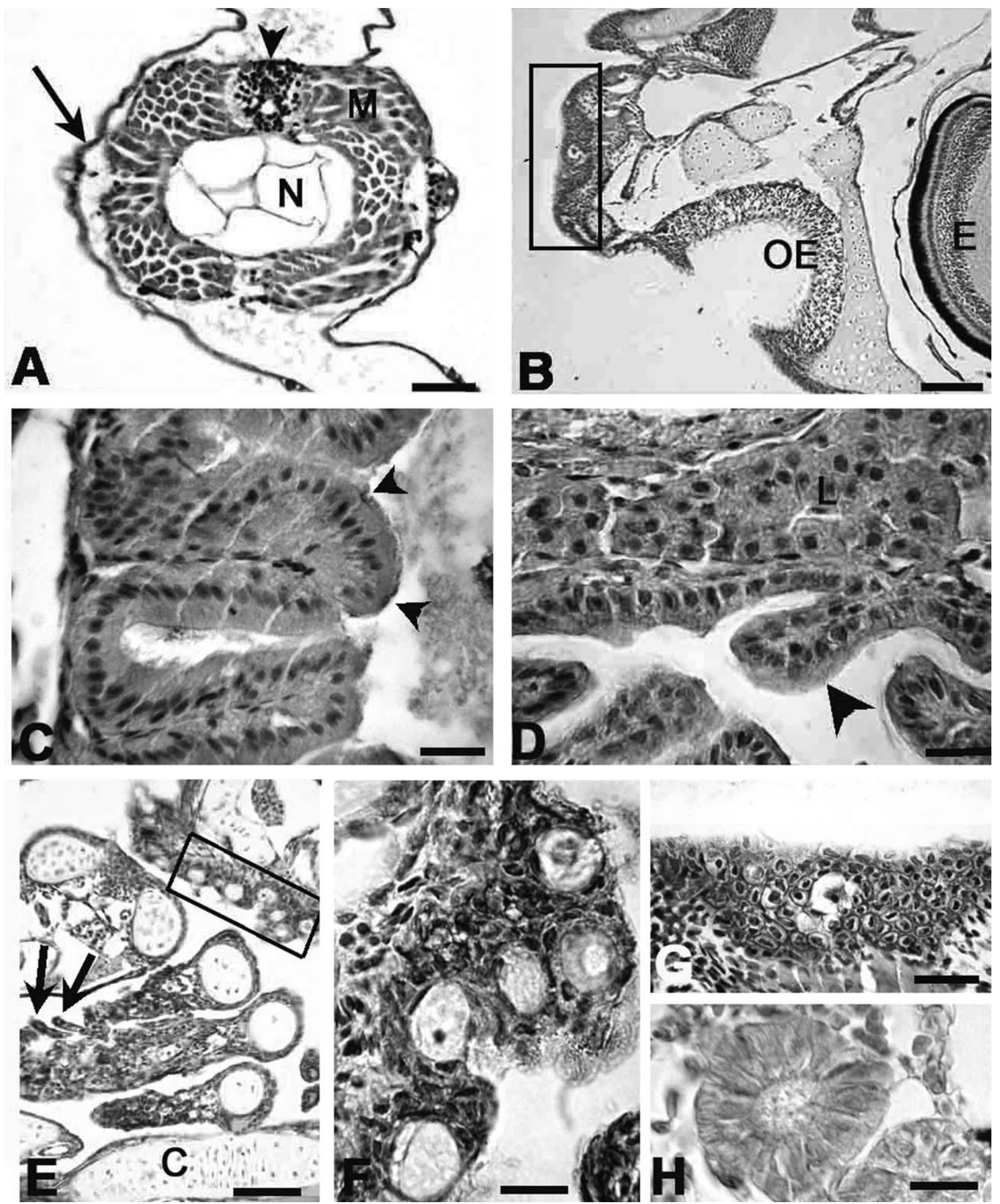
cells of yolk-granule-stage follicles (Fig. 5D), but no reaction could be detected in the testis (data not shown). In the hepatopancreas, IGF-II immunoreactivity was seen in scattered cells of liver parenchyma, whereas pancreatic islets were negative (Fig. 5E). An intense immunoreaction was also detected in the epithelial cells of the saccus vasculosus (Fig. 5F).

\section{Localization of IGF-II mRNA by in situ hybridization}

A positive hybridization signal for IGF-II was found in skeletal muscle at all ages studied (Fig. 6B, E-I). Figure 6A shows morphological detail of a myomere in a parasagittal semi-thin section at the trunk level of a 3-day-old larva. A similar section obtained from the hybridized whole-mount larva showed a positive signal in muscle fibres running in a parallel arrangement during the process of myofibrillogenesis (Fig. 6B). A positive hybridization signal was also found in the brain and in the eye of 3-day larva (Fig. 6C), in olfactory epithelium and in the pharynx epithelium of 5-day larva (Fig. 6D). At around 10-days post-hatching, IGF-II mRNA was detected in the myomeres of the trunk (Fig. 6E) and at midlarval life a high expression of IGF-II mRNA was found in the apical regions of myomeres and in the liver (Fig. 6F, G). A closer analysis of IGF-II mRNA localization was achieved by hybridizing paraffin sections of muscle from fry and adult with an IGF-II probe and use of fluorescent and confocal microscopy. A positive signal could be found in red muscle (Fig. 6H) and in fibres of the pink muscle (Fig. 6I).

\section{Discussion}

This study presents novel information on the spatial localization of IGF-II protein and mRNA from hatching to juvenile and adult stages in the gilthead sea bream, $S$. aurata, using immunohistochemistry and in situ hybridization. Expression of IGF-II in larval stages was also determined by northern blot analysis. The efficiency of the antibodies, which were raised against a synthetic peptide, in recognizing $S$. aurata IGF-II (saIGF-II) was tested by western blot using recombinant saIGF-II.

Although numerous studies (including our own work) using molecular biology techniques have demonstrated expression of the IGF-II gene during fish development and in adult fish tissues, information regarding the cellular localization of IGF-II in fish is lacking, and the physiological role of this growth factor in fish is not known. By using homologous antibodies against fish IGF-II, we have demonstrated that immunoreactive-IGF-II is present both in the liver and in extrahepatic tissues and organs of $S$. aurata, supporting a paracrine/autocrine mode of action for IGF-II in fish. This conclusion is further supported by the similar pattern of cellular localization found for IGF-II (this study) and both IGF-IR and IGFBP-2 (our previous reports). Immunoreaction to IGF-II was found in liver throughout the life cycle, although levels were moderate and lower than in several other tissues such as gut or kidney epithelia. In rats, liver exhibits the greatest expression of IGF-II during early development and decreases markedly during early postnatal life, to reach barely detectable levels in the adult (reviewed in Reinecke \& Collet 1998). In humans also, liver seems to be the major site for IGF-II expression but, unlike in rats, serum concentrations are low during development, increase after birth, and persist at high levels throughout life. Similarly, fish liver expresses high levels of IGF-II mRNA (Chen et al. 1994, Duguay et al. 1996, Tse et al. 2002). IGF-II is not accumulated in the liver and its concentrations in rainbow trout liver, as determined by homologous RIA, were $20 \%$ of those measured in the plasma (Gentil et al. 1996). Although binding proteins were shown to interfere with the measurement of IGF-II in plasma of rainbow trout (Gentil et al. 1996), it remains unknown to what extent IGF-II in fish is transported by IGFBPs in the circulation. A recent study showed that recombinant barramundi IGF-II had a lower affinity, compared with that of barramundi IGF-I, for IGFBPs present in the barramundi circulation, as demonstrated by the rapid clearance from the circulation (Degger et al. 2001).

A differential localization of IGF-I and IGF-II was found in $S$. aurata pancreas. IGF-I peptide and mRNA were high in $S$. aurata larval pancreas (which, at this early developmental stage, is localized near the intestinal walls) and in adult pancreatic tissue (already within the hepatopancreas) (Funkenstein et al. 1997, Perrot et al. 1999, G Radaelli, M Patruno, L Maccatrozzo \& B Funkenstein, unpublished observations). In contrast, no immunoreaction to IGF-II was detected in the pancreas at any developmental stage. These findings are in contrast to

\footnotetext{
Figure 3 Immunohistochemical localization of IGF-II in sea bream larvae. All panels are counterstained with haematoxylin. (A) Transverse section of a 3-day larva. Immunostaining is detected in the trunk musculature. Arrow, immunoreaction in skin; arrowhead, spinal cord; M, muscle; N, notochord. (B) Sagittal section of a 29-day larva. Immunoreaction is found in skin (boxed area), and olfactory epithelium (OE). E, eye. (C) Transverse section of a proximal intestine of a 36-day larva. Faint IGF-II reactivity is found in the cytoplasm of enterocytes (arrowheads). (D) Sagittal section of a 36-day larva, in which the apical part of the epithelial cells of the distal intestine shows intense immunoreactivity (arrowhead). The parenchyma of liver (L) exhibits a faint immunoreaction. (E) Sagittal section of a 36-day larva. Intense IGF-II immunoreactivity is present in the epithelium lining the gill filaments (arrows). Immunostaining is also found in the epithelium of the branchial cavity (boxed area). Cartilage (C) of the gill arches is negative. (F) Detail of branchial epithelium (boxed area of C) showing intense IGF-II immunoreactivity in the cytoplasm of the epithelial cells. (G) Detail of skin (boxed area of B) showing IGF-II immunoreactivity in cytoplasm of epithelial cells. (H) Head kidney of a 36-day larva showing faint immunostaining in the cytoplasm of the epithelium of a renal tubule. Bars represent: (A) $10 \mu \mathrm{m}$; (B) $20 \mu \mathrm{m}$; (C) $4 \mu \mathrm{m}$; (D) $4 \mu \mathrm{m}$; (E) $10 \mu \mathrm{m}$; (F) $2 \mu \mathrm{m}$; (G) $4 \mu \mathrm{m}$; (H) $4 \mu \mathrm{m}$.
} 

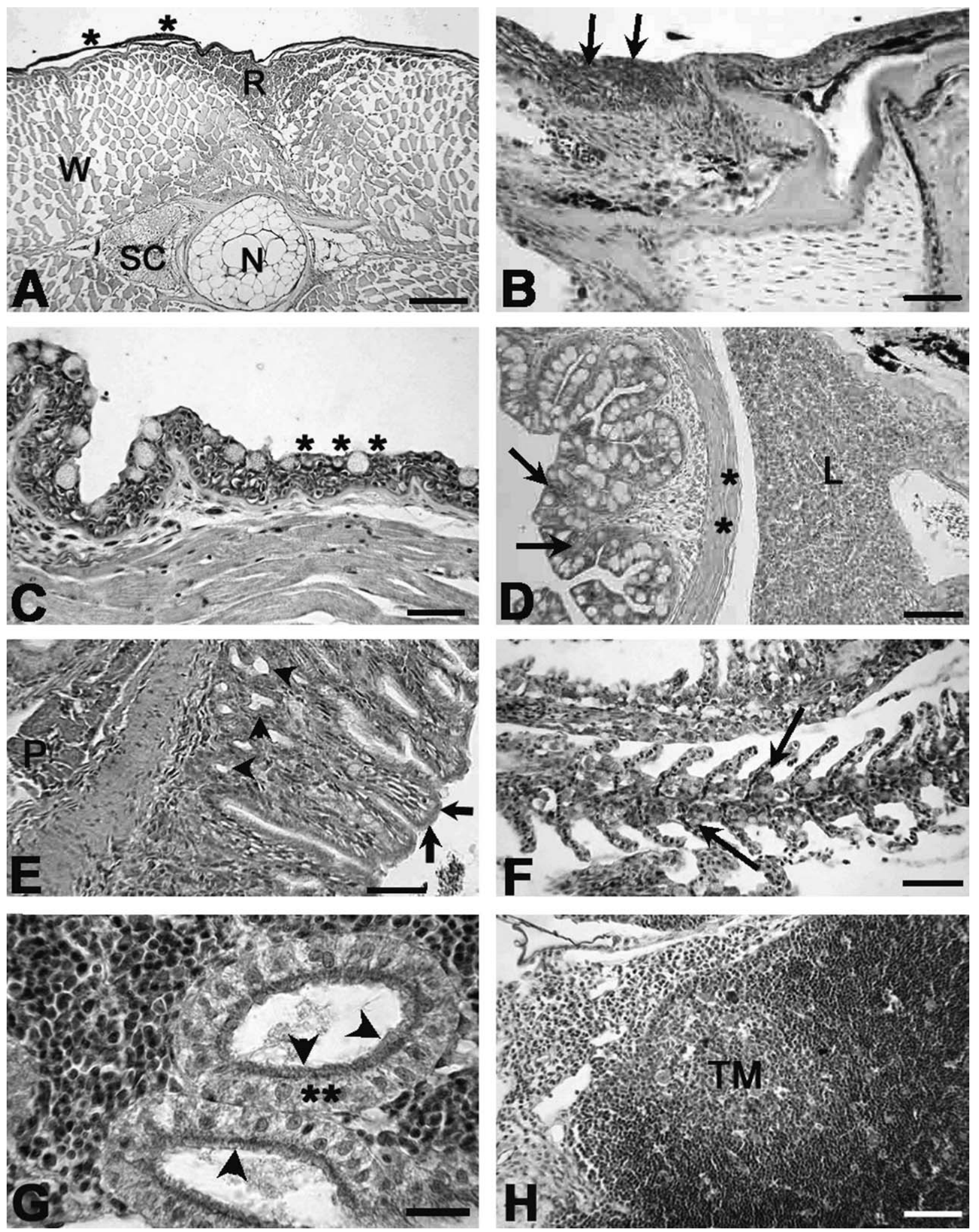
reports in mammals, in which IGF-II mRNA was detected in murine and human fetal pancreas and IGF-II peptide was produced by human fetal pancreas in culture (reviewed in Reinecke \& Collet 1998).

A novel observation in the present study was the intense IGF-II immunoreactivity found in the epithelia of pharynx and oesophagus, which agrees with high immunoreactivity for the IGF-IR that we have found in these cells in S. aurata and U. cirrosa (Perrot et al. 1999, Radaelli et al. 2003a). IGF-II immunoreactivity was also found in the stomach and in the intestine, with a more pronounced reaction in the distal part of the intestine, demonstrating again a pattern similar to that seen earlier with respect to IGF-IR (Perrot et al. 1999, Radaelli et al. 2003a). The similar localization of IGF-II and IGF-IR supports a paracrine/autocrine action of IGF-II in promoting the proliferation of epithelial cells in fish pharynx, oesophagus and intestine, in particular during development of these organs. This hypothesis is in line with findings in mammalian cells, where IGF-II binds with high affinity to the type 2 IGF receptor (also known as cation-independent mannose 6-phosphate receptor) (Morgan et al. 1987) and with the type 1 IGF receptor (Germain-Lee et al. 1992), and with a lower affinity to the insulin receptor (Morrione et al. 1997). In addition, several studies in mammals have indicated the importance of IGFs-I and -II in the regulation of intestinal cell proliferation (Zarrilli et al. 1994, Jehle et al. 1999, Simmons et al. 1999, Dignass \& Sturm 2001). The presence of IGF-II protein in the gastrointestinal apparatus is in agreement with the detection of IGF-II mRNA in carp and daddy sculpin intestine (Loffing-Cueni et al. 1999, Tse et al. 2002).

Another interesting finding in our study was the intense immunoreactivity for IGF-II peptide, in addition to IGF-II mRNA, in the olfactory epithelium of larvae and juveniles, consistent with the hypothesis that, in fish as in mammals, the IGF system is involved in the mitotic regulation of the olfactory epithelium (Giacobini et al. 1995, Federico et al. 1999). This hypothesis is supported by high IGF-IR and IGFBP-2 immunoreactivities found in the olfactory epithelium of $S$. aurata (Perrot et al. 1999) and $U$. cirrosa (Radaelli et al. 2003a). In our work we were not able to detect immunostaining in the brain, although low levels of IGF-II mRNA in the brain have been reported in the carp and daddy sculpin (Loffing-Cueni et al. 1999, Tse et al. 2002) and we found a positive reaction with IGF-II riboprobe in larval brain (Fig. 6C). In contrast, an intense reaction with IGF-II antibodies was found in saccus vasculosus of adult fish. This organ is found only in some species of teleost and elasmobranch fishes. It lies beneath the brain, posterior to the pituitary, and is composed of epithelial cells lining a lumen, which is continuous with that of the third ventricle. The epithelial cells separate the lumen from a dense network of capillaries. The function of the saccus has been suggested to be mainly concerned with homeostasis of the cerebrospinal fluid; others have suggested that it may be concerned with osmoregulation via the activity of ATPase enzymes involved in transport of $\mathrm{Na}^{+} / \mathrm{K}^{+}$and $\mathrm{Mg}^{2+} / \mathrm{Ca}^{2+}$ (Jansen et al. 1981). Observations of the presence of immunoreactive IGF-II (present study) and IGF-I (G Radaelli, M Patruno, L Maccatrozzo \& B Funkenstein, unpublished observations) in the saccus of $S$. aurata, together with previous reports on immunoreactive prolactin receptors in this organ of S. aurata (Santos et al. 2001) further support a role in osmoregulation. Other organs involved in osmoregulation also exhibited IGF-II immunoreactivity in the current study: skin, epithelial cells of the gill filaments and epithelium of kidney tubules. These cells were also positive for IGF-IR in S. aurata (Perrot et al. 1999) and U. cirrosa (Radaelli et al. 2003a). IGF-II gene expression has been found in gills and kidneys of several fish species (Chen et al. 1994, Duguay et al. 1996, Loffing-Cueni et al. 1999, Tse et al. 2002). The findings of several studies have suggested that IGF-I might be involved in osmoregulation in fish, but it remains unknown to what extent IGF-II also is involved in this function in fish. Interestingly, Degger et al. (2001) showed that, in juvenile barramundi, kidneys and gills were very effective at accumulating radiolabelled barramundi IGF-II. Taken together, the results obtained in this study and the fragmented data reported by others suggest that IGF-II might have a role in osmoregulation in fish. The availability of recombinant fish IGF-II will facilitate investigations of this possibility.

IGF-II immunoreactivity was also found in organs of the immune system: in the thymus, in the spleen and in some cells of the lymphatic tissue in the head kidney. Studies in a mammalian system, using mutant forms of IGF-II, demonstrated that IGF-II augments in vitro haematopoiesis, primarily through its interaction with

\footnotetext{
Figure 4 Immunohistochemical localization of IGF-II in sea bream fry. All panels are counterstained with haematoxylin. (A) Transverse section of a 77-day fry. IGF-II immunoreactivity is present in the trunk musculature at the level of red muscle fibres (R). White muscle fibres (W) are negative. *Immunoreaction in skin; SC, spinal cord; N, notochord. (B) Sagittal section, showing IGF-II immunoreactivity in the olfactory epithelium (arrows). (C) Pharynx of a 77-day fry showing intense immunoreactivity in the epithelium $\left(^{*}\right)$. (D) Oesophagus of a 95-day fry showing intense immunoreactivity in the epithelium (arrows) and faint reactivity in the striated musculature $(*)$. The parenchyma of liver (L) shows immunopositivity in some scattered cells. (E) Sagittal section of stomach of a 77-day larva, showing immunoreactivity in the epithelium (arrows) and in the gastric pits (arrowheads). The parenchyma of pancreas (P) is negative. (F) In a 77-day fry, immunoreactivity is present in the epithelium of the gill filaments; numerous cells located at the base of the secondary lamellae are reactive (arrows). (G) Kidney of a 95-day fry showing immunostaining in the epithelium of renal tubules $\left({ }^{*}\right)$; in some tubules the brush border is also immunoreactive (arrowheads). (H) Thymus medulla (TM) showing immunoreactivity in some scattered cells. Bars represent: (A) $10 \mu \mathrm{m}$; (B) $10 \mu \mathrm{m}$; (C) $10 \mu \mathrm{m}$; (D) $20 \mu \mathrm{m}$; (E) $10 \mu \mathrm{m}$; (F) $10 \mu \mathrm{m}$; (G) $4 \mu \mathrm{m}$; (H) $10 \mu \mathrm{m}$.
} 
IGF-IR and possibly insulin receptor, rather than IGF-II/ cation-independent mannose 6-phosphate receptors (Schwartz et al. 1996). It is not known whether IGF-II also has a role in haematopoiesis in fish. However, several lines of evidence, including our present findings, support this hypothesis: expression of IGF-II mRNA in the spleen of carp (Tse et al. 2002), immunoreactive IGF-IR in spleen, and lymphoid tissue present in the kidney of $S$. aurata (Perrot et al. 1999).

Expression of IGF-II in skeletal muscle was studied by immunohistochemistry and in situ hybridization from hatching to adult. In young larvae, expression of IGF-II
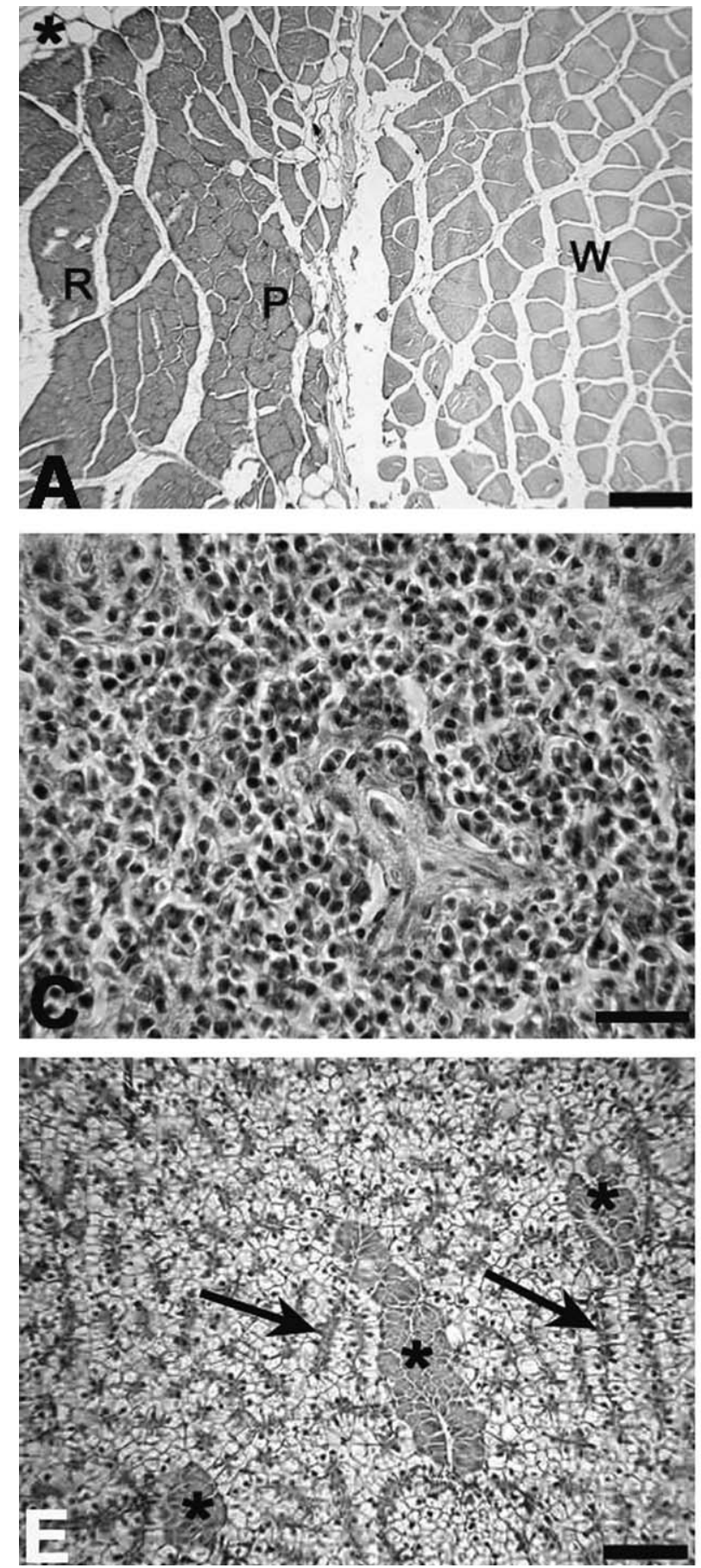
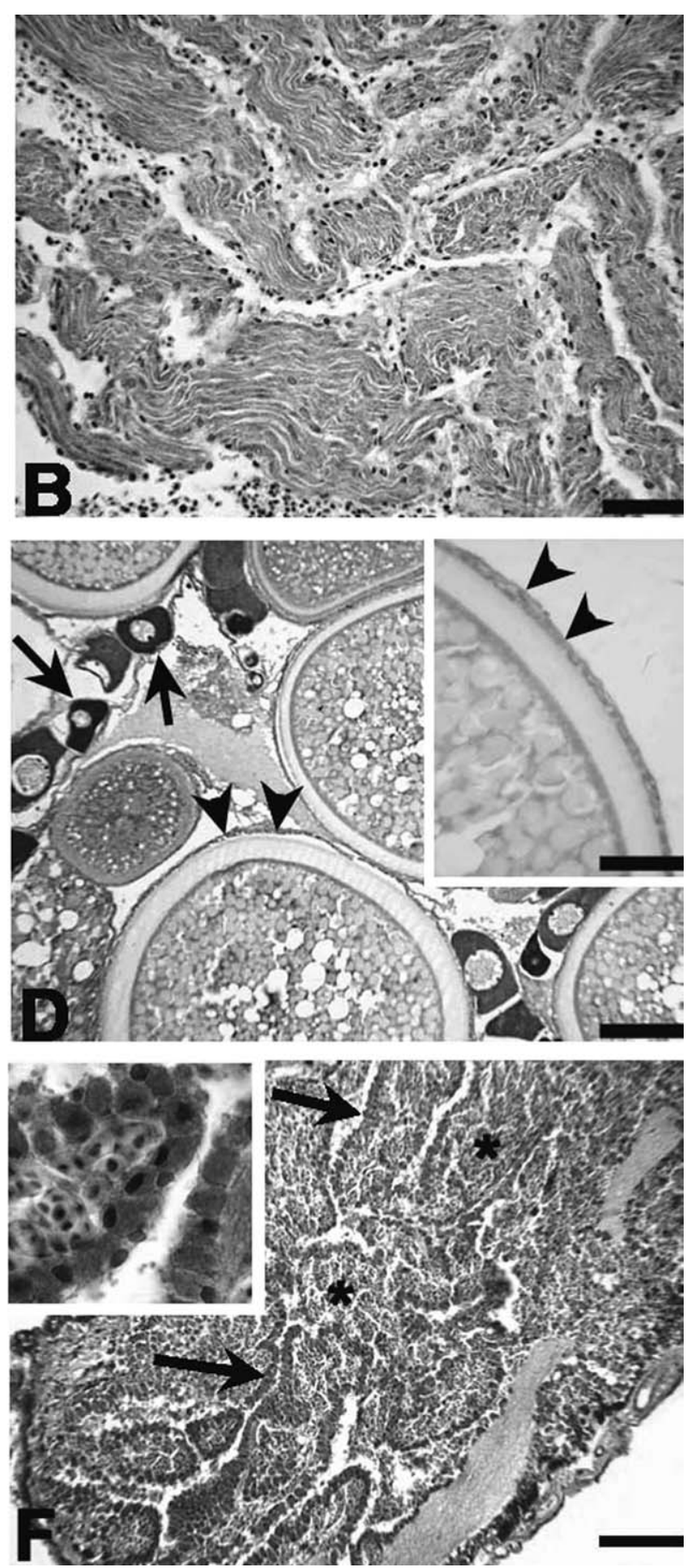
mRNA was detected in new fibres, which develop during the myofibrillogenesis process. At midlarval life a positive hybridization signal was found in the apical regions of the myomeres, which correspond to the zones of hyperplastic growth (Rowlerson et al. 1995, Rowlerson \& Veggetti 2001). A difference in the pattern of IGF-II immunoreactivity in red and white muscle was noted in muscle from juvenile and adult fish, being positive in red and pink muscle and negative in white muscle, similar to the pattern found for immunoreactive IGF-I (Perrot et al. 1999). These findings are consistent with a role for IGF-II as a growth regulator of fibres that develop slowly compared with fast-white muscle fibres. Although several studies have reported expression of IGF-II in fish muscle, including our own work (Chen et al. 1994, Duguay et al. 1996, Tse et al. 2002), this is the first demonstration of a differential pattern of production of IGF-II in fish red and white muscle. IGF-II immunoreactivity was also found in heart musculature of adult $S$. aurata, confirming the previous observation of high levels of IGF-II mRNA found in the heart from adult S. aurata (Duguay et al. 1996). Similarly, Loffling-Cueni et al. (1999) reported the expression of IGF-II mRNA in cardiac atrium. IGF-II mRNA levels were greater than those of IGF-I in hearts from juvenile and adult carp (Tse et al. 2002). Incorporation of radiolabelled IGF-II into hearts of juvenile barramundi (Degger et al. 2001) further supports a role for IGF-II in heart muscle physiology, as it points to the presence of IGF-IR in this organ. Indeed, high levels of IGF-IR mRNA were found in S. aurata heart (SJ Chan, personal communication). Finally, several studies in mammals and chickens have shown the importance of IGF-II for myocardial proliferation during fetal life or preservation of myocardial structure postinfarct (Armstrong et al. 2000, Kotlyar et al. 2001). It is worth noting that IGF-II immunoreactivity in skeletal and heart muscle, shown in this study, matches our results with respect to the cellular localization of myostatin in fish (Radaelli et al. 2003b), which is known as a negative regulator of muscle growth in mammals. The reciprocal changes in the expression of myostatin and IGF-II and IGF-IR have been suggested in myostatin-knockout mice (Kocamis et al. 2002).

The role of IGF-II in fish reproduction has not been fully elucidated. Expression of IGF-II in fish gonads had been demonstrated by us and by other researchers in several fish species - rainbow trout, tilapia, S. aurata, carp and daddy sculpin - using northern blot and RT-PCR analysis (Chen et al. 1994, Loffling-Cueni et al. 1999, Perrot \& Funkenstein 1999, Schmid et al. 1999, Perrot et al. 2000, Tse et al. 2002). In addition, IGF-II induced oocyte maturation (Kagawa et al. 1995) and DNA synthesis by isolated follicles (Srivastava \& Van der Kraak 1995). However, to our knowledge, the present study is the first demonstration, using a homologous antibody against fish IGF-II, of IGF-II immunoreactivity found in oocytes at the perinucleolus stage and in granulosa and theca cells of follicles at different developmental stages, supporting a role for IGF-II in oocyte maturation. This function of IGF-II is further supported by our previous findings of a similar cellular localization of IGF-IR (Perrot et al. 2000). A possible paracrine/autocrine role of IGF-II in the maturation of the ovary in mammals has been suggested by several authors (Levy et al. 1992, El-Roeiy et al. 1994, Mason et al. 1996). In the present study we were not able to find immunoreactivity in testis, in accordance with very low levels of IGF-II mRNA detected in the testis of several fish species, including $S$. aurata, by the sensitive method of RT-PCR (LoffingCueni et al. 1999, Perrot et al. 2000, Tse et al. 2002).

Finally, IGF-II mRNA in larvae during early developmental stages was found to be relatively high, as it was easily detected by northern blot analysis (Fig. 1). In contrast, IGF-I mRNA was hardly detectable by the use of this method (data not shown), despite the long exposure of the northern blot to X-ray film. These results are in agreement with earlier findings in mice, suggesting that IGF-II acts early in mouse embryogenesis, whereas the absence of IGF-I leads to growth defects later in development (Baker et al. 1993).

In conclusion, our data suggest that IGF-II has an important role during development and growth of $S$. aurata. Moreover, the generally similar pattern of cellular localization of IGF-II (this study) and IGF-IR and IGFBP-2 (our previous studies) supports our suggestion that IGF-II in fish exerts its role in a paracrine/autocrine mode of action, stimulating cell proliferation in a variety of fish tissues. Further studies are needed in order to demonstrate whether the immunoreactive IGF-II detected in the current study is proteolytically processed active protein or inactive proprotein.

\footnotetext{
Figure 5 Immunohistochemical localization of IGF-II in sea bream adults. All panels are counterstained with haematoxylin. (A) Transverse section of the trunk musculature showing immunostaining in red $(R)$ and pink (P) muscle fibres. White muscle fibres (W) are IGF-II negative. *Adipose tissue. (B) Striated myocardial fibres of the heart, showing IGF-II immunoreactivity. (C) Parenchyma of the spleen showing IGF-II immunoreactivity in scattered cells. (D) Mature ovary showing IGF-II immunoreactivity in oocytes at the perinucleolus stage (arrows) and in follicular cells (arrowheads). Inset: At higher magnification, immunoreactivity is visible in follicular cells (arrowheads). (E) Hepatopancreas shows IGF-II immunoreaction in the hepatocytes (arrows). The exocrine portion of the pancreatic tissue is negative $\left(^{*}\right)$. (F) The epithelium-like layer covering the saccus vasculosus (arrows) shows intense IGF-II immunoreaction. *Blood vessels. Inset: Detail of the immunoreactive epithelium-like layer covering the saccus vasculosus; immunoreactivity is in the cytoplasm. Bars represent: (A) $40 \mu \mathrm{m}$; (B) $10 \mu \mathrm{m}$; (C) $4 \mu \mathrm{m}$; (D) $20 \mu \mathrm{m}$, Inset $4 \mu \mathrm{m}$; (E) $20 \mu \mathrm{m}$; (F) $20 \mu \mathrm{m}$, Inset $4 \mu \mathrm{m}$.
} 

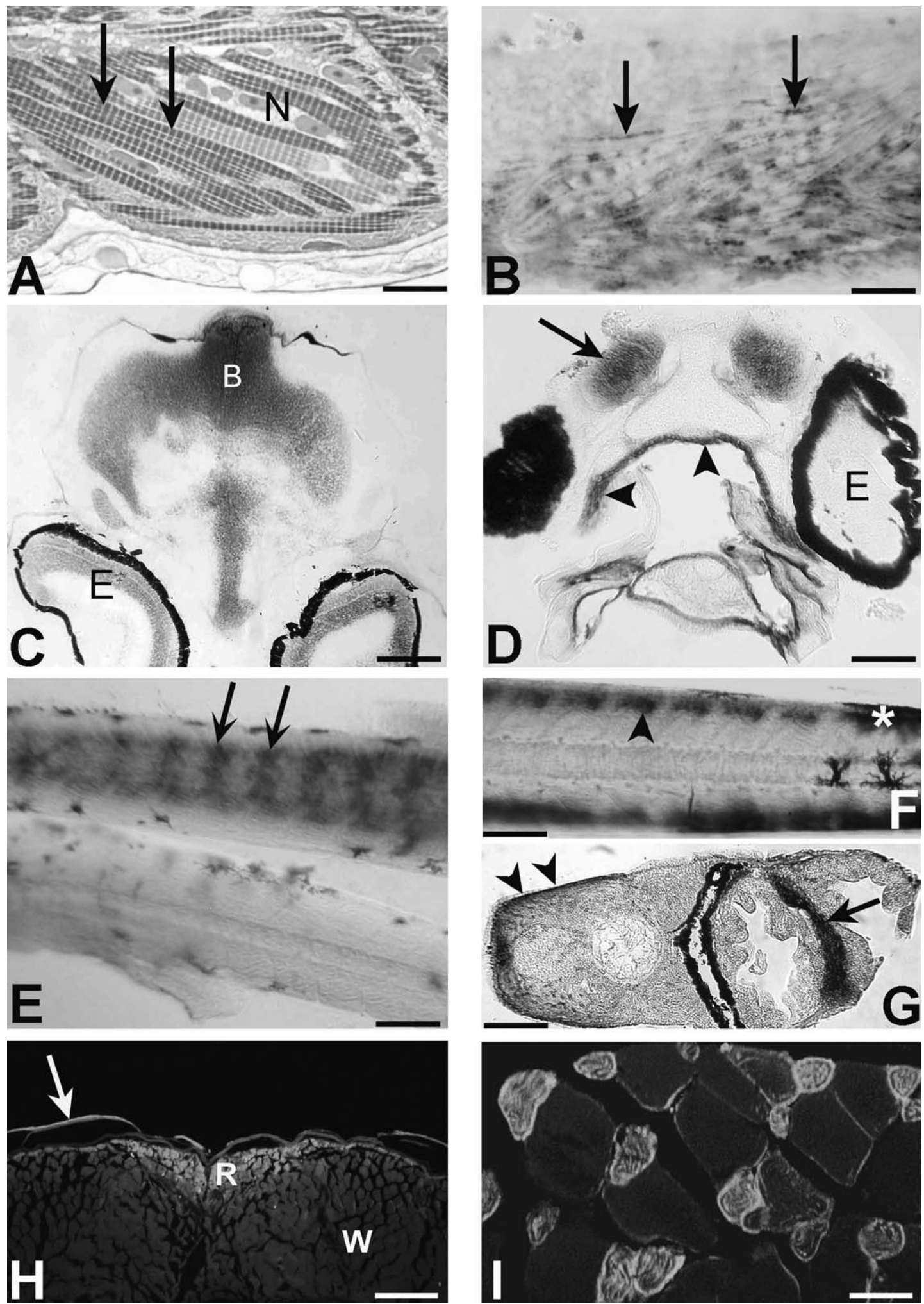


\section{Acknowledgements}

This work was supported by grants from the Italian Ministero dell'Università e della Ricerca Scientifica e Tecnologica (MURST) and of the University of Padua (Progetto di Ateneo 2001). The authors wish to thank Professor Cinzia Domeneghini for helpful discussion of the results, Mr G Caporale and Ms A Diman for their skilful technical work, and the team of The National Center of Mariculture, Eilat, for providing fish larvae and adult tissues. We are also grateful to Dr E Moiseeva for processing adult sea bream gonads and Dr V Perrot for providing the northern blot used in the current study.

\section{References}

Armstrong MT, Lee DY \& Armstrong PB 2000 Regulation of proliferation of the fetal myocardium. Developmental Dynamics 219 226-236.

Aviv H \& Leder P 1972 Purification of biologically active globin messenger RNA by chromatography on oligothymidylic acid cellulose. PNAS 69 1408-1412.

Ayson FG, de Jesus EG, Moriyama S, Hyodo S, Funkenstein B, Gertler A \& Kawauchi H 2002 Differential expression of insulinlike growth factor I and II mRNAs during embryogenesis and early development in rabbitfish, Siganus guttatus. General and Comparative Endocrinology 126 165-174.

Baker J, Liu JP, Robsertson EJ \& Efstradiatis A 1993 Role of insulinlike growth factors in embryonic and postnatal growth. Cell 75 73-82.

Chen TT, Shamblott M, Lin CM, Tang Y-L, Chan K-M, Cheng CL, Yang B-Y \& Marsh A 1994 Structure and evolution of fish growth hormone and insulin-like growth factor genes. In Perspectives in Comparative Endocrinology, pp. 352-364. Eds KG Davey, RE Peter \& SS Tobe. Ottawa, Canada: National Research Council of Canada.

Chen J-Y, Chang C-Y, Chen J-C, Shen S-C \& Wu J-L 1997 Production of biologically active recombinant tilapia insulin-like growth factor II polypeptides in Escherichia coli cells and characterization of the genomic structure of the coding region. DNA and Cell Biology 16 883-892.

Chen J-Y, Chen J-C, Chang C-Y, Shen S-C, Chen MS \& Wu J-L 2000 Expression of recombinant tilapia insulin-like growth factor-I and stimulation of juvenile tilapia growth by injection of recombinant IGFs polypeptides. Aquaculture 181 347-360.

Chomczynski P \& Sacchi N 1987 Single-step method of RNA isolation by acid guanidinium thiocyanate-phenol-chloroform extraction. Analytical Biochemistry 162 156-159.
Clark MS 1998 Fugu rubripes Cosmid 258N02 containing IGF-II, TH, NAP2 genes. EMBL database Accession No AL021880.

Collet C, Candy J, Richardson N \& Sara V 1997 Organisation, sequence and expression of the gene encoding IGF-II from barramundi (Teleosteii; Lates calcarifer). Biochemical Genetics 35 211-224.

Daughaday WH \& Rotwein P 1989 Insulin-like growth factors I and II. Peptide, messenger ribonucleic acid and gene structures, serum, and tissue concentrations. Endocrine Reviews 10 86-91.

DeChiara TM, Efstratiadis A \& Robertson EJ 1990 A growthdeficiency phenotype in heterozygous mice carrying an insulin-like growth factor II gene disrupted by targeting. Nature 345 78-80.

Degger B, Richardson N, Collet C \& Upton Z 2001 Production, in vitro characterization, in vivo clearance, and tissue localization of recombinant barramundi (Lates calcarifer) insulin-like growth factor II. General and Comparative Endocrinology 123 38-50.

Del Giacco L, Diani S \& Cotelli F 2000 Identification and spatial distribution of the mRNA encoding an egg envelope component of the Cyprinid zebrafish, Danio rerio, homologous to the mammalian ZP3 (ZPC). Development Genes and Evolution 210 41-46.

Dignass AU \& Sturm A 2001 Peptide growth factors in the intestine. European Journal of Gastroenterology and Hepatology 13 763-770.

Duguay SJ, Lai-Zhang J, Steiner DF, Funkenstein B \& Chan SJ 1996 Developmental and tissue-regulated expression of IGF-I and IGF-II mRNAs in S. aurata. Journal of Molecular Endocrinology 16 123-132.

Duval H, Rousseau K, Elies G, Le Bail PY, Dufour S, Boeuf G \& Boujard D 2002 Cloning, characterization, and comparative activity of turbot IGF-I and IGF-II. General and Comparative Endocrinology 126 269-278.

El-Roeiy A, Chen X, Roberts VJ, Shimasakai S, Ling N, LeRoith D, Roberts CT Jr \& Yen SS 1994 Expression of the genes encoding the insulin-like growth factors (IGF-I and IGF-II), the IGF and insulin receptors, and IGF-binding proteins-1-6 and the localisation of their gene products in normal and polycystic ovary syndrome ovaries. Journal of Clinical Endocrinology and Metabolism $\mathbf{7 8}$ 1488-1496.

Federico G, Maremmani C, Cinquanta L, Baroncelli GI, Fattori B \& Saggese G 1999 Mucus of the human olfactory epithelium contains the insulin-like growth factor-I system which is altered in some neurodegenerative diseases. Brain Research 835 306-314.

Funkenstein B, Almuly R \& Chan SJ 1997 Localization of IGF-I and IGF-I receptor mRNA in $S$. aurata larvae. General and Comparative Endocrinology 107 291-303.

Funkenstein B, Tsai W, Maures T \& Duan C 2002 Ontogeny, tissue distribution, and hormonal regulation of insulin-like growth factor binding protein-2 (IGFBP-2) in a marine fish, S. aurata. General and Comparative Endocrinology 128 112-122.

Gentil V, Martin P, Smal J \& Le Bail P-Y 1996 Production of recombinant insulin-like growth factor-II in the development of a radioimmunoassay in rainbow trout (Oncorhynchus mykiss). General and Comparative Endocrinology 104 156-167.

Figure 6 In situ hybridization using an IGF-II probe in developing sea bream. (A) Detail of a myomere in parasagittal semi-thin section at the trunk level in a 3-day larva. Arrows indicate the new muscle fibres that are produced during the myofibrillogenesis process, as indicated by the presence of many centrally aligned swollen nuclei $(\mathrm{N})$. Section is stained with crystal violet and basic fuchsin. (B) Parasagittal section obtained from the hybridized whole mount of a 3-day larva in which positive signal is found in new muscle fibres (arrows) running in a parallel arrangement into myomeres. (C) Transverse section through the cephalic region of a 5-day larva showing the hybridization signal in the brain (B). A faint reactivity is also present in eyes (E). (D) Transverse section of the same larva as shown in the previous panel; the hybridization signal is present in the olfactory tissue (arrow) and in the pharynx epithelium (arrowheads). E, eye. (E) In a 10-day larva (top sample) an intense hybridization signal is found in myomeres of the developing trunk (arrows). Bottom larva depicts the sense experiment. (F) In a whole-mount 36-day larva, the hybridization signal is found in the apical part of the myomeres (arrowheads). *Melanophores. (G) In a hybridized 29-day larva, transversely sectioned, the signal is present in the apical regions of the myomeres (arrowheads) and in liver (arrow). (H) Fluorescent in situ hybridization reveals strong staining in the area close to the lateral line and in the skin (arrow) of a 77-day fry. R, positive red muscle; W, white muscle. (I) In adult sea bream, specific staining is evident in the small pink fibres of the mosaic, demonstrated by fluorescent in situ hybridization. Bars represent: (A) $1 \mu \mathrm{m}$; (B) $20 \mu \mathrm{m}$; (C) $20 \mu \mathrm{m}$; (D) $20 \mu \mathrm{m}$; (E) $40 \mu \mathrm{m}$; (F) $40 \mu \mathrm{m}$; (G) $40 \mu \mathrm{m}$; (H) $40 \mu \mathrm{m}$; (I) $10 \mu \mathrm{m}$. 
Germain-Lee EL, Janicot M, Lammers R, Ullrich A \& Casella SJ 1992 Expression of a type I insulin-like growth factor receptor with low affinity for insulin-like growth factor II. Journal of Biochemistry 281 413-417.

Giacobini MMJ, Zetterström RH, Young D, Hoffer B, Sara V \& Olson L 1995 IGF-I influences olfactory bulb maturation. Evidence from anti-IGF-I antibody treatment of developing grafts in oculo. Developmental Brain Research 84 67-76.

Gluckman PD \& Ambler GR 1993 What is the function of circulating insulin-like growth factor-2 in postnatal life? Molecular and Cellular Endocrinology $92 \mathrm{C} 1-\mathrm{C} 3$.

Greene MW \& Chen TT 1997 Temporal expression pattern of insulin-like growth factor mRNA during embryonic development in a teleost, rainbow trout (Onchorynchus mykiss). Molecular Marine Biology and Biotechnology 6 144-151.

Greene MW \& Chen TT 1999 Quantitation of IGF-I, IGF-II, and multiple insulin receptor family member messenger RNAs during embryonic development in rainbow trout. Molecular Reproduction and Development 54 348-361.

Han VK, Lund PK, Lee DC \& D'Ercole AJ. 1988 Expression of somatomedin/insulin-like growth factor messenger ribonucleic acids in the human fetus: identification, characterization, and tissue distribution. Journal of Clinical Endocrinology and Metabolism 66 422-429.

Humbel RE 1990 Insulin-like growth factors I and II. European Journal of Biochemistry 190 445-462.

Jansen WF, Flight WFG \& Zanderbergen MA 1981 Fine structure localization of adenosine triphosphatase activity in the saccus vasculosus of the rainbow trout, Salmo gairdneri Richardson. Cell and Tissue Research 219 267-279.

Jehle PM, Fussgaenger RD, Blum WF, Angelus NK, Hoeflich A, Wolf E \& Jungwirth RJ 1999 Differential autocrine regulation of intestine epithelial cell proliferation and differentiation by insulinlike growth factor (IGF) system components. Hormones and Metabolic Research 31 97-102.

Joly JS, Joly C, Schulte-Merker S, Boulekbache H \& Condamine H 1993 The ventral and posterior expression of the evenskipped homeobox gene eve 1 is perturbed in dorsalized and mutant embryos. Development 119 1261-1275.

Jones JI \& Clemmons DR 1995 Insulin-like growth factors and their binding proteins: biological actions. Endocrine Reviews 16 3-34.

Kagawa H, Kobayashi M, Hasegawa Y \& Aida K 1995 Insulin and insulin-like growth factors I and II induce final maturation of oocytes of red seabream, Pagrus major, in vitro. General and Comparative Endocrinology 95 293-300.

Kelley KM, Schmidt KE, Berg L, Sak K, Galima MM, Gillespie C, Balogh L, Hawayek A, Reyes JA \& Jamison M 2002 Comparative endocrinology of the insulin-like growth factor-binding protein. Journal of Endocrinology 175 3-18.

Kocamis H, Gahr SA, Batelli L, Hubbs AF \& Killefer J 2002 IGF-I, IGF-II, and IGF-receptor-1 transcript and IGF-II protein expression in myostatin knockout mice tissues. Muscle and Nerve 26 55-63.

Kotlyar AA, Vered Z, Goldberg I, Chouraqui P, Nas D, Fridman E, Chen-Levy Z, Fytlovich S, Sangiorgi G, Spagnoli LG, Orlandi A, Savion N, Eldar M \& Scheinowitz M 2001 Insulin-like growth factor I and II preserve myocardial structure in postinfarct swine. Heart 86 693-700.

Levy MJ, Hernandez E, Adashi EY, Stillman RJ, Roberts CT Jr \& LeRoith D 1992 Expression of the insulin-like growth factor (IGF)-I and -II and the IGF-I and -II receptor genes during postnatal development of the rat ovary. Endocrinology 131 1202-1206.

Loffing-Cueni D, Schmid AC \& Reinecke M 1999 Molecular cloning and tissue expression of the insulin-like growth factor II prohormone in the bony fish Cottus scorpius. General and Comparative Endocrinology 113 32-37.
Mason HD, Cwyfan-Hughes SC, Heinrich G, Franks S \& Holly JM 1996 Insulin-like growth factor (IGF) I and II, IGF-binding proteins, and IGF-binding protein proteases are produced by theca and stroma of normal and polycystic human ovaries. Journal of Clinical Endocrinology and Metabolism 81 276-284.

Maures T, Chan SJ, Xu B, Sun H, Ding J \& Duan C. 2002 Structural, biochemical, and expression analysis of two distinct insulin-like growth factor I receptors and their ligands in zebrafish. Endocrinology 143 1858-1871.

Morgan DO, Edman JC, Standring DN, Fried VA, Smith MC, Roth RA \& Rutter WJ 1987 Insulin-like growth factor II receptor as a multifunctional binding protein. Nature 329 301-307.

Moriyama S, Ayson FG \& Kawauchi H 2000 Growth regulation by insulin-like growth factor-I in fish. Bioscience Biotechnology and Biochemistry 64 1553-1562.

Morrione A, Valentinis B, Xu SQ, Yumet G, Louvi A, Efstratiadis A \& Baserga R 1997 Insulin-like growth factor II stimulates cell proliferation through the insulin receptor. PNAS 94 3777-3782.

Nieto MA, Patel K \& Wilkinson DG 1996 In situ hybridization analysis of chick embryos in whole mount and tissue sections. Methods in Cell Biology 51 219-235.

Palamarchuk AY, Holthuizen PE, Müller WEG, Sussenbach JS \& Kavsan VM 1997 Organization and expression of the chum salmon insulin-like growth factor II gene. FEBS Letters 416 344-348.

Palamarchuk AY, Kavsan VM, Sussenbach JS \& Holthuizen PE 1999 The chum salmon IGF-II gene promoter is activated by hepatocyte nuclear factor $3 \beta$. FEBS Letters 446 251-255.

Perrot V \& Funkenstein B 1999 Cellular distribution of insulin-like growth factor II (IGF-II) mRNA and hormone regulation of IGF-I and IGF-II mRNA expression in rainbow trout testis (Oncorhynchus mykiss). Fish Physiology and Biochemistry 20 219-229.

Perrot V, Moiseeva EB, Gozes Y, Chan SJ, Ingleton P \& Funkenstein B 1999 Ontogeny of the insulin-like growth factor system (IGF-I, IGF-II, and IGF-IR) in gilthead seabream (S. aurata): expression and cellular localization. General and Comparative Endocrinology 116 445-460.

Perrot V, Moiseeva EB, Gozes Y, Chan SJ \& Funkenstein B 2000 Insulin-like growth factor receptors and their ligands in gonads of a hermaphroditic species, the gilthead seabream ( $S$. aurata): expression and cellular localization. Biology of Reproduction 63 229-241.

Peter RE \& Marchant TA 1995 The endocrinology of growth in carp and related species. Aquaculture 129 299-321.

Radaelli G, Domeneghini C, Arrighi S, Bosi G, Patruno M \& Funkenstein B 2003a Localization of IGF-I, IGF-I receptor and IGFBP-2 in developing Umbrina cirrosa (Pisces: Osteichthyes). General and Comparative Endocrinology 130 232-244.

Radaelli G, Rowlerson A, Mascarello F, Patruno M \& Funkenstein B $2003 b$ Myostatin precursor is present in several tissues in teleost fish: a comparative immunolocalization study. Cell and Tissue Research 311 239-250.

Reinecke M \& Collet C 1998 The phylogeny of the insulin-like growth factors. International Review of Cytology 183 1-94.

Rowlerson A \& Veggetti A 2001 Cellular mechanisms of postembryonic muscle growth in aquaculture species. In: Muscle Development and Growth, Fish Physiology, vol 18, pp 103-140. Ed IA Johnston. San Diego: Academic Press.

Rowlerson A, Mascarello F, Radaelli G \& Veggetti A 1995 Differentiation and growth of muscle in the fish S. aurata (L), II: hyperplastic and hypertrophic growth of lateral muscle from hatching to adult. Journal of Muscle Research and Cell Motility 16 223-236.

Santos CRA, Ingleton PM, Cavaco JEB, Kelly PA, Edery M \& Power DM 2001 Cloning, characterization, and tissue distribution of prolactin receptor in the sea bream ( $S$. aurata). General and Comparative Endocrinology 121 32-47.

Schagger H \& Von Jagow G 1987 Tricine-sodium dodecyl sulfatepolyacrylamide gel electrophoresis for the separation of proteins in the range from 1 to $100 \mathrm{kDa}$. Analytical Biochemistry 166 368-379. 
Schmid AC, Näf E, Kloas W \& Reinecke M 1999 Insulin-like growth factor-I and -II in the ovary of a bony fish, Oreochromis mossambicus, the tilapia: in situ hybridisation, immunohistochemical localisation, Northern blot and cDNA sequences. Molecular and Cellular Endocrinology 156 141-149.

Schwartz GN, Warren MK, Sakano K, Szabo JM, Kessler SW, Pashapour A, Gress RE \& Perdue JF 1996 Comparative effects of insulin-like growth factor II (IGF-II) and IGF-II mutants specific for IGF-II/CIM6-P or IGF-I receptors on in vitro hematopoiesis. Stem Cells 14 337-350.

Shamblott MJ \& Chen TT 1992 Identification of a second insulin-like growth factor in a fish species. PNAS 89 8913-8917.

Simmons JG, Pucilowska JB \& Lund PK 1999 Autocrine and paracrine actions of intestinal fibroblast-derived insulin-like growth factors. American Journal of Physiology 276 G817-G827.

Singh JS, Rall LB \& Styne DM 1991 Insulin-like growth factor I and II gene expression in $\mathrm{Balb} / \mathrm{C}$ mouse liver during postnatal development. Biology of the Neonate 60 7-18.
Srivastava RK \& Van der Kraak G 1995 Multifactorial regulation of DNA synthesis in goldfish ovarian follicles. General and Comparative Endocrinology 100 397-403.

Tse MCL, Vong QP, Cheng CHK \& Chan KM 2002 PCR-cloning and gene expression studies in common carp (Cyprinus carpio) insulin-like growth factor-II. Biochimica et Biophysica Acta 1575 63-74.

Zarrilli R, Pignata S, Romano M, Gravina A, Casola S, Bruni CB \& Acquaviva AM 1994 Expression of insulin-like growth factor (IGF)-II and IGF-I receptor during proliferation and differentiation of CaCo-2 human colon carcinoma cells. Cell Growth and Differentiation 5 1085-1091.

Received 21 March 2003

Accepted 8 May 2003

Made available online as an Accepted Preprint 12 May 2003 